\title{
Éditorial
}

\section{Perspectives actuelles en contrôle postural}

Le contrôle postural est une thématique centrale dans les recherches sur le mouvement humain. La stabilité posturale est une base essentielle pour la précision des actions finalisées, et sa dégradation liée à l'âge ou à diverses maladies neurologiques est un problème clé dans le domaine de la réhabilitation. Psychologues et neuroscientifiques ont insisté sur le rôle des boucles de feedback et des processus anticipatoires dans l'adaptation en continu de la posture. Les tenants de l'approche des systèmes dynamiques ont analysé l'émergence des synergies posturales, en réponse à l'évolution des contraintes. La dynamique particulièrement complexe du centre de gravité et du centre des pressions, même durant le maintien de la station debout, a été analysée au moyen de méthodes diverses, incluant des approches non linéaires hautement sophistiquées. Une grande diversité de modèles, psychologiques, neuro-musculaires, dynamiques, biomécaniques, ont été invoqués pour rendre compte de la complexité du contrôle postural. Ainsi, ce champ de recherche concentre les débats principaux et les controverses qui ont marqué la recherche en contrôle moteur ces dernières décennies.

L'objectif de ce numéro spécial est de présenter une photographie de la recherche actuelle dans le domaine du contrôle postural. Nous avons invité quelques-uns des meilleurs chercheurs à soumettre un manuscrit présentant une synthèse de leurs travaux passés, ou proposant des points de vue novateurs ou des directions pour les recherches futures. La plupart d'entre eux ont répondu positivement, et j'aimerais ici remercier tous les auteurs pour leurs contributions. Ce numéro est composé d'articles théoriques, méthodologiques, et d'autres contributions plus appliquées ou à orientation clinique. Il donne une belle image de la diversité et de la richesse de ce domaine de recherche.

La première partie de ce numéro spécial présente quelques points de vue théoriques innovants sur le contrôle postural.

- Mike Riley, Nikita Kuznetsov, et Scott Bonnette (Université de Cincinnati, USA) s'interrogent sur la pertinence du concept de «système de contrôle postural », considéré comme un système générique et permanent. Ils proposent un point de vue alternatif, suggérant que le contrôle postural est réalisé par des synergies posturales à assemblage souple, spécifiques à chaque situation. Ce point de vue est supporté par une large revue des travaux basés sur les analyses non-linéaires, mettant en évidence les propriétés (multi)fractales de la dynamique posturale et leur dépendance à l'égard des contraintes.

- Tom Stoffregen (Université du Minesotta, USA) présente un point de vue particulièrement convaincant sur l'origine du mal des transports. L'auteur questionne les théories classiques basées sur l'idée d'un conflit intersensoriel, et propose une nouvelle théorie considérant le mal des transports comme un trouble transitoire du contrôle postural.

- Didier Delignières, Kjerstin Torre et Pierre Louis Bernard (Université Montpellier 1, France) développent une hypothèse nouvelle, considérant que le contrôle postural est essentiellement un contrôle de la vitesse, plutôt qu'un contrôle de la position. L'étude présentée montre que des variables expérimentales estimant l'étendue du bornage de la vitesse sont plus sensibles que des variables basées sur la position, pour rendre compte des effets de facteurs expérimentaux.

La seconde partie est composée de revues de question, offrant des présentations approfondies de programmes spécifiques de recherche.

- Ludovic Marin et Benoît Bardy (Université Montpellier 1, France) présentent les fondements des deux principales théories du contrôle postural : l'approche neuromusculaire, et l'approche dynamique. Ces approches sont questionnées au travers de deux questions fondamentales : Comment peut-on contrôler simultanément les multiples parties composant notre corps? Comment peut-on adopter la posture la plus efficace, parmi la myriade de possibilités offertes?

- Matthieu Boisgontier, Jean-Baptiste Mignardot, Vincent Nougier, Isabelle Olivier et Estelle Palluel (Université Joseph-Fourier, Grenoble, France) proposent une revue centrée sur l'analyse du coût attentionnel du contrôle postural. Cet article montre comment le coût attentionnel est affecté par un certain nombre de facteurs, dont la focalisation du sujet sur le contrôle postural, la disponibilité des informations 
sensorielles, la complexité de la tâche posturale, et des variables individuelles telles que l'expertise ou l'âge.

- Christine Assaiante (Université de Provence, France) présente une revue complète d'une approche fonctionnelle du développement moteur, basée sur la maîtrise graduelle de la coordination, de l'adaptation et de l'anticipation au niveau du contrôle postural, au fil de l'ontogénèse. Cet article décrit le lent développement du contrôle postural, qui semble se poursuivre jusqu'à des étapes tardives de l'enfance et de l'adolescence.

Enfin la troisième partie traite de perspectives de réhabilitation, et met l'accent sur les problèmes posturaux liés à la maladie ou l'avancée en âge.

- Lauren Mak, Ting Ting Yeh, Jason Boulet, Tyler Cluff et Ramesh Balasubramaniam (Université McMaster, Hamilton, Canada) rapportent une expérimentation dont le but était d'analyser l'interaction entre un feedback visuel retardé et une tâche cognitive ajoutée sur le contrôle postural chez les personnes âgées. Chez des sujets jeunes, on observe une réduction de la variabilité de la posture en situation de double-tâche, alors que les sujets âgés ne semblent pas bénéficier de cette situation de double-tâche. Les auteurs suggèrent que cet effet reflète une modulation insuffisante de l'attention chez les personnes âgées, résultant dans des instabilités dans le contrôle de l'équilibre.

- Déborah Varoqui, Benoît Bardy et Jacques-Yves Pélissier (Rehabilitation Institute of Chicago, USA, et Université Montpellier 1, France) montrent l'intérêt de l'approche dynamique pour quantifier les déficits posturaux, en termes d'anormalités spatiotemporelles de patterns de mouvement. Centrés sur l'hémiplégie, ils suggèrent que l'analyse des patterns de coordination posturale apporte des informations plus pertinentes que l'étude de variables indirectes telles que la trajectoire du centre des pressions, et proposent que protocoles novateurs de (ré)apprentissage et des perspectives thérapeutiques pour les patients post-AVC.

- Inke Marie Albertsen et Jean-Jacques Temprado (Université Aix-Marseille 2, France) analysent la possible influence d'une supplémentation haptique sur les mécanismes d'intégration multi-sensorielle dans les systèmes de contrôle postural déficients. Ils présentent un prototype de cane informationnelle, et suggèrent d'intéressantes perspectives pour le développement des gérontotechnologies.

- Adeline Tanzi, Marlène Mathias et Patrice Rougier (Université de Savoie, France) analysent les effets d'un entraînement sur une balancelle sur les capacités posturales. Ils montrent qu'après pratique, la variabilité de la distance entre le centre des pressions et le centre de gravité tend à décroître, révélant une amélioration des stratégies posturales.

On aura remarqué que ce numéro spécial est bilingue, avec une moitié des articles en français et l'autre en anglais. Chaque auteur était en fait libre de s'exprimer dans la langue de son choix. Cette présentation bilingue déroutera peut-être certains, mais correspond à notre sens à l'usage de l'anglais dans la recherche actuelle : un usage décomplexé, où l'on doit sans problème pouvoir naviguer d'une langue à l'autre. Il n'est pas dans les objectifs de Science \& Motricité de se livrer à une défense acharnée de la langue française, mais de rendre compte de la réalité de la recherche dans notre domaine. Ce numéro spécial à notre sens en donne une bonne image, internationale et multilingue. 


\section{Editorial}

\section{Current perspectives in postural control}

Postural control is a central topic in human movement studies. Postural stability is essential for supporting accurate goal-directed actions, and its impairment with aging and neurological diseases is a key problem in the domain of rehabilitation. Postural control has been investigated from a number of different perspectives. Psychologists and neuroscientists have emphasized the role of feedback loops and anticipatory processes in the continuous adaptation of posture. Proponents of the dynamical systems approach have analyzed the emergence of postural synergies in response to changing constraints. The very complex dynamics of the centre of mass and the centre of pressure, even during quiet stance, have been analyzed using diverse methods, including highly sophisticated, nonlinear approaches. Various psychological, neuromuscular, dynamical, or biomechanical models have been advocated for accounting for the complex organization of postural control. As such, this field of research is multidisciplinary in nature and concentrates the major debates and controversies that have marked motor control research in the last decades.

The aim of this Special Issue is to present the current state-of-the-art in this domain. We invited some of the leading researchers to submit papers presenting an overview of their past work or proposing innovative points of view for future directions for research. Most of them answered positively, and I would like to thank very warmly all authors for their contributions. This issue is composed of theoretical, methodological, and more clinical and applied contributions, giving a nice picture of the diversity and the richness of this field of research.

The first section of this Issue presents innovative theoretical considerations about postural control.

- Mike Riley, Nikita Kuznetsov, and Scott Bonnette (University of Cincinnati, USA) challenge the concept of "postural control system", considered a static system of fixed components. They propose an alternative point of view, suggesting that postural control is rather achieved by situation-specific, softy assembled postural synergies. Their approach is supported by a comprehensive review of empirical studies using nonlinear analyses, evidencing the (multi)fractal properties of posture dynamics and their dependence to constraints.

- Tom Stoffregen (University of Minesotta, USA) presents a very convincing point of view about the etiology of motion sickness. The author challenges the traditional accounts based on the concept of intersensory conflict, and proposes a new theory considering motion sickness as a transient postural control disorder.
- Didier Delignières, Kjerstin Torre and Pierre Louis Bernard (Montpellier-1 University, France) support the hypothesis that postural control is essentially a control of velocity, rather than a control of position, as commonly assumed. The paper shows that empirical variables estimating the velocity bounding range are more sensitive than position-based variables for revealing the effects of experimental factors.

The second section is composed of theoretical reviews that provide extensive overviews of some specific research programs.

- Ludovic Marin and Benoît Bardy (Montpellier-1 University, France) present the foundations of two main theories of postural control, namely the neuromuscular approach and the dynamical approach. These approaches are questioned with respect to two fundamental issues : how can we simultaneously control all parts of our body? How can we adopt the most efficient posture among the myriad of postural possibilities?

- Matthieu Boisgontier, Jean-Baptiste Mignardot, Vincent Nougier, Isabelle Olivier and Estelle Palluel (University Joseph-Fourier, Grenoble, France) propose a review focusing on the attentional cost of postural control. This paper shows that the attentional cost is affected by several factors, including the focalisation of attention on postural control, the availability of sensory information, the complexity of the postural task, and individual characteristics such as expertise or age.

- Christine Assaiante (University of Provence, France) presents an extensive review of a functional approach to motor development, based on a gradual mastering of coordination, adaptation and anticipation in postural control in the course of ontogenesis. This paper describes the very progressive development of postural control, which seems to continue up to late periods during childhood and adolescence.

Finally, the third section is devoted to rehabilitation perspectives, and focuses on postural issues related to disease or aging.

- Lauren Mak, Ting Ting Yeh, Jason Boulet, Tyler Cluff and Ramesh Balasubramaniam (McMaster University, Hamilton, Canada) present an analysis of the effect of interaction between delayed visual feedback and a cognitive secondary task on postural control in elderly. Young adults showed a decrease in postural variability in the dual-task conditions, but older 
adults, in contrast, did not benefit from dual-task performance. The authors suggest that these results reflect an insufficient modulation of attention in elderly, resulting in instabilities in balance control.

- Déborah Varoqui, Benoît Bardy and Jacques-Yves Pélissier (Rehabilitation Institute of Chicago, USA, and Montpellier-1 University, France) highlight the interest of the dynamical approach to quantify postural deficits, in terms of spatio-temporal abnormalities of movement patterns. Focusing on hemiplegia, they show that the analysis of postural coordination patterns provides more relevant information than the study of indirect variables such as the centerof-pressure trajectory. They suggest some innovative (re-)learning protocols for future therapies in poststroke population.

- Inke Marie Albertsen and Jean-Jacques Temprado (University of Aix-Marseille 2, France) analyze the possible influence of haptic supplementation on multisensory integration mechanisms in impaired postural control systems. They present a prototype of informational cane providing haptic supplementation, and suggest interesting perspectives for the development of gerontechnologies.

- Adeline Tanzi, Marlène Mathias and Patrice Rougier (University of Savoy, France) analyze the effect of training on a seesaw on postural capacities. They show a decrease of the variance of the distance between centre-of-pressure and centre-of-gravity after practice, indicating an improvement of balance strategies.

As one can notice, this special issue is bilingual, with one half of the articles in French and the other in English. Each author was actually free to choose the language of his/her manuscript. Some French researchers decided to write in French, because their papers (especially reviews) could be very useful for French undergraduate students. Some others decided to propose their manuscript in English, in order to communicate toward a broader, international audience. In both cases the abstract is presented in the two languages, and will help those that do not master both languages to however benefit from the entire issue.

Didier Delignières Main Editor 